\title{
Economic Evaluation of Seoul City's Bus-Only-Lane Project
}

\author{
YOOYEON NOH $^{*}$ AND KYE WOO LEL ${ }^{* *}$
}

Following the suit of some other countries, the Seoul Metropolitan Government has ambitiously implemented the bus-only-lane (BOL) system as one of the new transportation reform plans. However, it docs not seem that the project has achicved its primary goal of reducing the number of privatc vehicle drivers, and that the project is economically viabic. This paper reports the results of an economic cvaluation of Samil-Ro Bus-Only-Lane project, one of the representative BOLs in Seoul. It estimates travel demand both with and without project in order to examine the achievement of the project's goal of shifting private vehicle travelers to the reformed bus system. To test the project's cconomic viability, the paper also conducts a cost-bencfit analysis by calculating the discounted net present value (NPV), internal rate of return (IRR), and benefit and cost ratio (B/C). Moreover, both the project's uncirtainty and sustainability have been checked through the sensitivity and risk analysis and the environmental degradation effects test, respectively. In the conclusion. the paper also provides policy recommendiations.

Keyuords: Bus-Only-Iane, Seoul (ity, net-present-value (NPV), internal rate of return (IRR), uncertainty, sustainability, environmental impact.

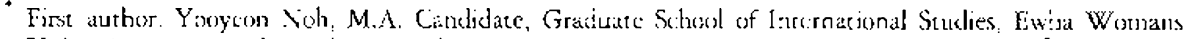

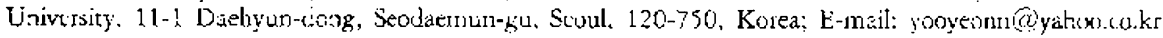

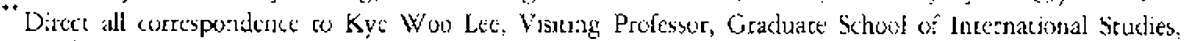
Scoul National University, San 56, Shinlim-shnes, Gwanak-ku, Seoul, 151.742 Kntra; Tel: 82-2-880-9250; E-mai:: KWLEE(ciewhd.ackr
} 


\section{IN"IRODLC'IION}

$\mathrm{O}$ ver the last several decades, rapid population growth and urbanization led to a sharp increase in demand for urban transport facilities and services in many major cities around the workl. However, factors such as inadecuate devclopment planning and inefficient government instruments prevented the timely and effective implementation of public cansportation. Dissatisfaction with the level and quality of public transportation services led those people who can afford it to turn to private modes of transport. Consequently, many cities ate facing serious problems, including significant levels of traftic congestion, air pollution, and high accident rates.

In a response to these problems, many cities and national guvernments began studying or implementing projects to increase the bus transport efficiency, the latter being the most flexible and widely used means of public transport for the foresceable future.' 'lhey understand that by giving buses special lanes in the center of the road, buses can often move faster, which improve scrvice for transit passengers and induce many people to give up private cars and shifr to using buses. The followings are examples of major cities that implenented bus-only-lanes (BOL) system and motivated the Scoul Metropolitan Government to follow suit.

\section{Curitiba, Brazil}

Ihe most commonly citied BUL example is found in Curitiba, Brazil, a city of 1.6 million people. Here, they established five bus-only-lanes on the citys prodominant arteries, on which abour 1,100 buses make 12,500 trips per day and serve 1.3 million passengers. Besides buses running on BOL, a simple and innovative device contributed to specding up the bus: a glass-and-steel boarding station shaped like a tube, allowing fare purchases to take place at the vehicle door level, without the use of steps. Morcover, bus stops are built into the urhan streerscape and offer distinctive, enhanced waiting amenities, passenger information, pre-boarding fare payment, wheelchair lifts, lighting at all bus doors, and raised platforms to facilitate rapid boarding. After the $\mathrm{BOL}$ project implementation, average bus speed increased up to $20 \mathrm{~km}$ per hour and $70 \%$ of Curitibais commurers use bus transport, $28 \%$ of the latter figure previously reporced to be private car drivers (Lee and Kinl 2004).

\section{Bogota, Columbia}

With a significant increase in private car unership and the contraction of bus routes, the Bogota Metropolitan Government adopted the BOL system as part of its Transwilenio (Transpore for the New Millennium) project. Bogota, a city of fice million in Colombia, opcrates its 42 -kilometer BOL system, where 235 
buses make trips at an average speed of $26 \mathrm{~km}$ per hour. After the operation, the system carrics more than 800,000 passengers a day, which is 3.7 times higher than before its implementation (Lee and Kinn 2004).

\section{Pittsburg, Pennsylvania}

Pittsburg, a city of 1.4 million, is the first city to implement the BOI. system in North America. The bus-only-lane was established on three routes totaling $29.4 \mathrm{~km}$, on which 240 buses make trips at an average speed of $40 \mathrm{~km}$ per hour and serve 48,000 passengers (l.ee and Kim 2001).

\section{SEOUL CITY'S BUS-ONLY-LANE PROJECT}

Traffic demand in Korca rapidly increased over the last several decades, causing problems such as road traffic congestion, traffic accidents, and noise and air pollution. In the case of Seoul, home to some 10.2 million people in 2004 , traffic demand has increased rapidly while urban mobile efficiency level has significantly decrcased. Moreover, with car ownership rising sharply in Korea, Scoul's vast bus system has been increasingly losing street space and average speed to private vehicles, and consequently rnode-share and revenue. Recently, registered motor vehicles in metropolitan Seoul increased at an average annual rate of $3.9 \%$, reaching 2.8 million vehicles in 2004 (Seoul Metropolitan 'Transport Statistics). ${ }^{2}$ But because of huge road conseruction costs, environmental damage concerns, and objections from citizen groups, roald supyly has reached its limits. While citizens complained about high gasoline prices, air pollution from traffic, car accidents, and inconvenicnce caused by raffic congestion, transportation problems in Seoul continued to worsen.

As a countermeasurc against these problems, the Seoul Metropolitan Government launched a new transportation reform plan in July 2004. The most salient point of the plan was to introduce the bus-only-lane (BOI.) project, which reserves the median lane exclusively for buses in major thoroughfares. Consequently, road surfaces for personal cars decreases. By 2004 , Scoul installed four BOL routes totaling $36 \mathrm{~km}$, and in 2005 , thirteen routes totaling $162.4 \mathrm{~km}$ were created step by step (Chon 2004). Many poople remarked that the project was too ambitious as it aimed at diverting passengers and vehicles to different modes of transportarion by radically changing existing road surface usage and bus-routing systems. Similar bus reform projects implemented several rimes in the past were not successful.

The main objective of the recent bus reform plan is two-fold: 1) to enhance the speed and efficiency of the bus system; and 2) to mitigate traffic jams by atcracting regular commuters away from personal cars and making them more dependent on public transportation (Seoul Metropolitan Government 2004). Seoul City expected that the BOL project would make personal car drivers switch to 
the public bus system for two reasons. First, as a result of the exclusive bus-only-lane, a bus' driving speed would increase sufficiently to attract average citizens commuting in their own cars during rush hour to the bus system. Second, as personal cars would lose road surface relative to the past, driving speed would decrease to the point that there would be sufficient incentive to stop driving personal cars.

A year after the new bus system went inte effect, it is questionable whether or not the Seoul Metropolitan Government's main objectives were achieved. After implementarion, there were a series of accidents and technical glitches, including rush-hour engine breakdowns causing major disruptions in downtown Scoul. Morc importantly, people complain that the new system is very inconvenient and complicated while it makes traffic congestion worse.

In this paper, we will examine the effects of a new bus system in Seoul, focusing un the Samil-Ro Bus-Only-Lane. We chose the Samil-Ro BOL not only because it is one of the earliest and representative BOL.s in Scoul, but it is also one of the busiest roads and will well represent the effects of the BOl. project on the city's general craffic condition. The BOL project will be cvaluated by using economic analysis tools to check its cconomic efficiency and viability. In other words, besides accounting for the project entity's financial costs and benefits in the usual way, we quantify the impact that the project has on the national economy, including costs and benefits of the major targeted bencficiaries and other stakcholdcrs of the project. In this way, we can infer whether or not the project has been oconomically viable, and the investment fund has been put into a worthy project in comparison with other competing investment opportunities.

The analyeded projece is Samil-Ro Bus-Only-Lane, which consists of five intersections (Jongro 2 ga, Cheoggye $2 \mathrm{ga}$, Fuljiro 2 ga, Myungdong Church, and Tatgero 2 ga). The total length of the road is $1.099 \mathrm{~km}$, having three platforms. The total reconstruction of Samil-Ro lasted from July 22, 2003 to July 20, 2004, hut the bus-only-way system became operative from May 1, 2004. This evaluation is made after one full year of operation.

In the following section, we present forecasted travel demand for the Samil-Ro Bus-Only-Iane Project. 'I he fourth scction analyzes the project's economic viability by identifying: quantifying, valuating, and comparing costs and benefits. In the fifth section, we measure the uncertainty and sustcinability of the project, including the envirommental impact of the project. Lastly, the conclusion summarizes the project's main effeces and provides policy recommendations.

\section{TRAVEL DEMAND FORECASTING}

Forccasting and evaluating travel demand is an important step in initiating the cconomic analysis of a transport project. This process requires the application of sophisticated mathematical techniques. By using data from the Construction Safety 
Management Office of Scoul City, we calculated traffic volume and average driving speed of vehicles on Samil-Ro with and without the project and compared the differences. Both sets of data were calculated as averages of several observations at the same locations over time. The observation perind of without-project was from April 26 to April 30, 2004 while a more accurate investigation for the with-project took a little mote time, lasting from May 3 to May 1/4, 2004.

Table I shows observed traffic flows on Samil-Ro at three different times during the day, when the road gets most congested. On the one hand, with the project in the afternoon and evening, the number of both observed buses and personal vehicles declined compared to the without-the-project situation. Accordingly, driving speeds in the evening and afternoon increased significantly, by $80.9 \%$ and $87.2 \%$ fur buses, and $7.2 \%$ and $14.8 \%$ for pcrsonal vehicles, respcctivcly. These results prove that the project contributed to the enhancement of the bus system in terms of increasing bus driving speed and efficient road surface use for both buses and private vehicle drivers. However, it is difficult to say that the project transformed personal vehicle travelics to reformed bus tiders, as the number of both buses and private vehicles decreased. 'This is contrary to the expectation that an increased number of buses would substitute for the number of private vehicles on the road.

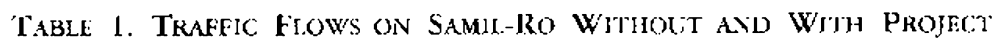

(Lirit: number of cars; \%)

\begin{tabular}{|c|c|c|c|c|c|c|c|}
\hline \multirow{5}{*}{$\begin{array}{l}\text { Tratic } \\
\text { Volume } \\
\text { (car/hour) }\end{array}$} & \multirow{5}{*}{$\begin{array}{c}\text { Morning } \\
\{8: 00 \sim 9: 00) \\
\text { Aftcrnoon } \\
(13: 00 \sim 14: 00) \\
\text { Evening } \\
(18: 00 \sim: 9: 00)\end{array}$} & \multicolumn{2}{|c|}{ Without Project } & \multicolumn{2}{|c|}{ With Project } & \multicolumn{2}{|c|}{ Rate of Change } \\
\hline & & \multirow{2}{*}{$\begin{array}{l}\text { P.V** } \\
2,208\end{array}$} & \multirow{2}{*}{$\begin{array}{r}\text { HI TS } \\
216\end{array}$} & \multirow{2}{*}{$\frac{P . V^{*}}{2,104}$} & \multirow{2}{*}{$\begin{array}{r}\text { BL'S } \\
281\end{array}$} & \multirow{2}{*}{$\begin{array}{r}\text { P.Y.* } \\
8.9\end{array}$} & \multirow{2}{*}{$\begin{array}{r}\text { BUS } \\
31.4\end{array}$} \\
\hline & & & & & & & \\
\hline & & 2,436 & 205 & 2,315 & 186 & -5.0 & -9.3 \\
\hline & & 2,513 & 194 & 2,508 & 193 & -0.2 & -0.5 \\
\hline Average & $\begin{array}{c}\text { Morning } \\
\langle 8: 0(1--): 00)\end{array}$ & 32 & 12.1 & 11.35 & 17.15 & -5.4 & 41.7 \\
\hline $\begin{array}{l}\text { Driving } \\
\text { Speed }\end{array}$ & $\begin{array}{c}\text { Afternoon } \\
(13: 00 \cdots 14: 00)\end{array}$ & 8.1 & 9 & 9.3 & 16.85 & 14.8 & 87.2 \\
\hline (km/hour) & $\begin{array}{c}\text { Eveniag } \\
(18: 00) \sim 19:(00)\end{array}$ & 8.3 & 9.45 & 8.9 & 17.1 & 7.2 & 80.9 \\
\hline
\end{tabular}

VOTt: * P.V. sta:eds for Prisate Vichick

SOURCE: Construction Safety Management Office of Seoul City 2004

On the other hand, with the project, the number of buses observed in the morning increased by $31.4 \%$, and their speed increased by $41.7 \%$, while the number of personal cars increased somewhat by $8.9 \%$ percent, and their speed decreasing sligbrly to $5.4 \%$ percent. These resules also enable us to infer that the project 
contributed to the increase in bus driving speed. Howcver, the project failed to cncourage private vehicle travelers to ride buses. Contrary to expectations, private vehicle operators increased compared to the without project situation. In short, the project achicved one objective, i.e., increasing the driving speed of huses, but it has not succeeded in achieving the second objective, i.e., shifting private vehicle drivers to the reformed bus system.

Next, we analyze a set of data regarding delays on the road. Figures 1, 2, and 3 compare the rate of delay; of general traffic, including both private vethicles and buses, at four intersections on Samil-Ro (without project to with project). Only Cheonggye 2 ga shows some improvement in all three different times a day, while areas like Luljiro 2 ga and Jongro 2 ga turn out to be much worse in the morning, and Jongro 2 ga, Myungdong, and 'Tacgeto 2 ga in the evening. In the morning, the rate of delay of general traffic at Euljiro 2 ga intersection incrcased from 71.3 secicar to $131.2 \mathrm{sec}$ car, and in the evening, the rate of delay of general traffic at Tacgero 2 ga intersection increased from $23.5 \mathrm{sec} / \mathrm{car}$ to 54.9 sec/car after the project.

Figtire 1. Rate of Delay Comparison (Morying)

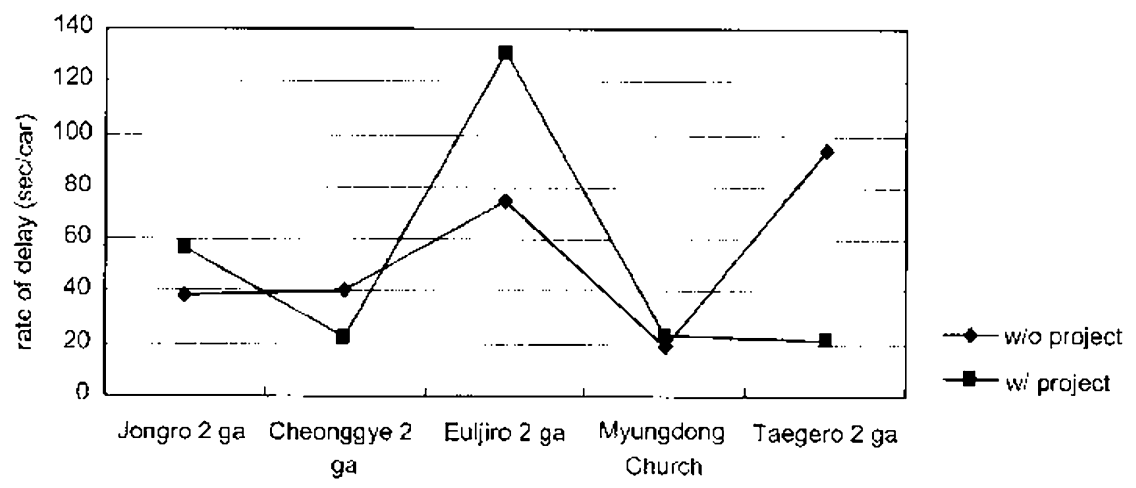

Figute 2. Rati of Delay Comparison (AFteknoON)

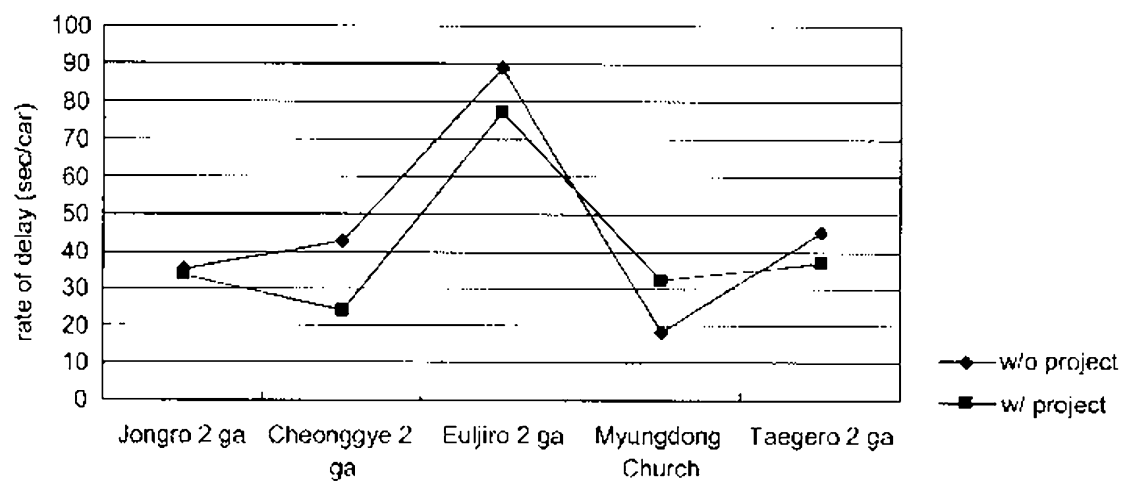


Ficrise 3. Rate of Delay Comparison (Evfning)

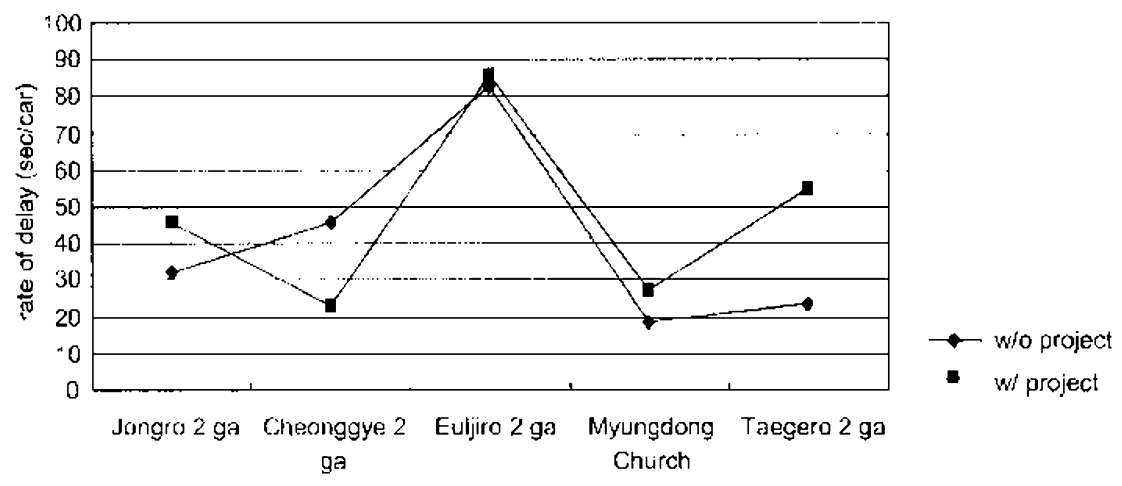

\section{COSTS AN1 BENEFITS ANALYSIS}

In this section, we present the methodology cmployed and results obtained when evaluating the economic costs and benefits derived from the Samil-Ro BLOO project. Such analysis requires making certain assumptions, which may have an important influence on the final result. Since this necessarily implies a certain degree of arbitrariness, they should be explicit at the outset. There also needs to be a sensitivity analysis, which will illustrate the degree with which they may influcince the results.

At the outsct, the quantification of the present value of the flows of costs and benefits generated by the project recpures the detcrmination of both its useful life and the discount rate, which is used to convert future values into present ones. We have considered a period of twenty ycats for the project's longevity and a discount ratc of $7.5 \%$. Both values arc usually adopted in the economic evaluation of transport infrastructures in Korea (KDI 2001).

\section{Identifying and Quantifying Costs and Benefits}

\section{(1) Costs}

We can divide custs related to the Samil-Ro BOL project into two types: construction and maintenance costs. 'The construction period lasted two years prior to the project operation, and the total construction cost was estimated at KRW 12,970 million. Table 2 shows that construction costs include costs for civil works, land reparation, and professional lees for supervision. Table 3 shows yearly estimated maintcnance costs, calculated based on the practices of the Korean Development Inscitue (KDI) (sec Table 3). 
IAHIE 2. CONSTRLCIION COSIS

(Unit: KRW milion)

\begin{tabular}{l|c|c|c}
\hline & First Year (2003) & Sccond Year (2004) & Total \\
\hline Civil Work & 1,800 & 2,700 & 4,500 \\
Land Reparation & 2,490 & 5,810 & 8,300 \\
Professional fees for Stpervision & 170 & - & 170 \\
Sub-Fotal & 4,460 & 8,510 & $\mathrm{i} 2,970$ \\
\hline
\end{tabular}

SOURCE: Scoul City Office of Infrastructure Management 2004

Table 3. Yearly Maintenance Costs

(Unit: KRW inillion)

\begin{tabular}{c|c|c|c|ccc|c|c|c|c|c}
\hline Year & 1 & 2 & 3 & 4 & 5 & 6 & 7 & 8 & 9 & 10 \\
Cost & 27 & 30 & 36 & 42 & 51 & 60 & 70 & 82 & 94 & 106 \\
\hline Year & 11 & 12 & 13 & 14 & 15 & 16 & 17 & 18 & 19 & 20 \\
\hline Cost & 121 & 133 & 152 & 170 & 188 & 207 & 228 & 249 & 271 & 295 \\
\hline
\end{tabular}

SOLRCE: Seoui City Office of lnerast:uctute Managernent $200 \%$

\section{(2) Benefits}

Two types of benefits are taken into account in this analysis. The first is due to a reduction in vehicle's operaring costs, and the other is due to travel time savings.

\section{Reduction of Vebicle Operating Custs (VOC)}

Savings in vehicle operating costs (VOC) ate the most easily measurable benefit from transport projects. Vehicle operating costs (VOC) split into fuel costs, engine oil costs, tire costs, maintenance costs, and depreciation costs. Changes in those costs provoked by the existctace of the Samil-Ro BOL can be calculated as a function of changes in number of kilometers traveled and also of traveling speed, as follows:

$$
\mathrm{VOC}=\sum\left(\mathrm{Dl}{ }_{k i} \times \mathrm{VT}_{\dot{k}} \times 365\right)
$$

where the total length of road times the number of cars is $\left.\mathrm{D}\right|_{k l}$, and the unit cost of vehicle uperation per speed is $V T_{\dot{s}}$

Unit costs that depend on different traveling speeds are computed using the coefficients in Table 4 . These values are also obtained from a KDI report (2001). 
Tabi: 4. Cofifeichents tsed to Convert Traveled Speed into Opfrating Costs

\begin{tabular}{|c|c|c|c|c|c|c|c|}
\hline & $\begin{array}{l}\text { Speed } \\
(\mathrm{km} / \mathrm{h})\end{array}$ & Fucl & $\begin{array}{c}\text { Engine } \\
\text { Oil }\end{array}$ & $\begin{array}{l}\text { Tire } \\
\text { Cost }\end{array}$ & $\begin{array}{c}\text { Maincenance } \\
\text { Cost }\end{array}$ & $\begin{array}{c}\text { Depreciation } \\
\text { Cost }\end{array}$ & $\begin{array}{l}\text { Total } \\
\left(W_{011}\right)\end{array}$ \\
\hline \multirow{11}{*}{$\begin{array}{l}\text { Private } \\
\text { Veluicle }\end{array}$} & 10 & 57.35 & 6.26 & 0.43 & 7.23 & 150.35 & 221.62 \\
\hline & 20 & 34.58 & 5.21 & 0.79 & 8.54 & 128.14 & $: 77,26$ \\
\hline & 30 & 29.41 & 1.52 & 1.22 & 10.12 & 109.35 & 154.62 \\
\hline & 40) & 26.56 & $3 \times 2$ & $1.7 \%$ & 10.5 & 92.26 & 134.92 \\
\hline & 50 & $27.1 \cdot 1$ & $3 \times 2$ & 2266 & 11.83 & 78.59 & 123.64 \\
\hline & 60 & 28.17 & 3.82 & 2.87 & .2 .49 & 70.90 & 118.25 \\
\hline & i0 & $29.7 \%$ & 3.82 & 3.5 .1 & 13.14 & 64.92 & 115.1 .1 \\
\hline & 80 & 30.16 & 3.18 & $4.2 \%$ & $14 \div 6$ & $58.0 \%$ & 110.76 \\
\hline & 90 & 33.12 & 3.13 & 5.14 & 11.85 & 53.82 & 110.11 \\
\hline & 100 & 35.11 & 3.82 & $6.1:$ & 15.77 & 5006 & 111.53 \\
\hline & 110 & 38.63 & 4.87 & 7.51 & 37.48 & 45.19 & 114.28 \\
\hline \multirow{5}{*}{$-\cdot$} & 20 & 43.31 & 7.30 & 8.93 & 19.06 & 40.49 & 119.08 \\
\hline & 10 & $6 ? .11$ & 6.36 & 0.35 & 7.26 & $17: 08$ & 247.14 \\
\hline & $? 0$ & 41.01 & 5.76 & 0.61 & 8.20 & 141.33 & 196.91 \\
\hline & 30 & 32.01 & 5.15 & 0.99 & 9.03 & 116.04 & 163.22 \\
\hline & 40 & 31.06 & $1.5 / 4$ & 1.38 & 931 & 96.70 & 142.09 \\
\hline \multirow{8}{*}{ Blas } & 50 & 26.07 & 4.54 & $1.7 \overline{7}$ & 10.21 & 83.31 & 125.93 \\
\hline & 60 & 28.35 & 4.24 & $2.2:$ & 10.72 & 73.64 & $\$ 19.15$ \\
\hline & 70 & 29.97 & $3 \% 4$ & 2.76 & 11.18 & 66.20 & 114005 \\
\hline & 80 & 31.06 & 3.61 & $3.5:$ & $\therefore 2.1$ & 59.31 & 104.69 \\
\hline & 190 & 34.06 & 3.53 & 109 & 13.32 & 54.60 & 109.50 \\
\hline & 100 & 36.42 & 3.33 & 4.86 & 14.34 & 50.58 & $: 09.53$ \\
\hline & 110 & 40. & 3.64 & 5.9 & 15.55 & 46.12 & 112.23 \\
\hline & $1>0$ & 45.91 & 124 & 7.18 & 16.76 & 4240 & 116.49 \\
\hline
\end{tabular}

SOl:RC: Korea Develepment lastitute 200 :

\section{Value of Time Sanings (VOT:}

Time savings are an important benefit of transpor project, since timc is a valuable resource. When converting absolute time values into monetary units, we need to choose a value for travel-time savings. Most literature considers that the value of time sived depends on the purpose of the rrip. Working trips are valued at the value of output produced, while trips undertaken for pleasure are valued at 
the individual's willingness to pay for leisure time, which is usually valued at one-chird of the value of working trips (Belli et a). 2001). Since this can be a controversial calcularion, we have decided to employ the values recommended by the Korea Development Institute (KDI). Through in-depth calculation and analysis, KDr came up with the rosult that the average time value per hour saved for a privare vehicle is worth KRW9,697 while that for one bus amounts to KRW72,7।7. The value of time savings was calculated as follows:

$$
\operatorname{VOT}=\left\{\mathrm{L}^{\prime}\left(\mathrm{T}_{k !} \times \mathrm{P}_{*} \times \mathrm{Q}_{k !}\right)\right\} \times 365
$$

where the total traveled time is $T_{k \prime}$, the average time value pes different rype of car is $P_{k}$, and the number of vehicles that pass the road is $Q_{k}$

\section{Valuating and Comparing Costs and Benefits}

Table 3 shows the cost-benefit valuation results in the form of net present value (NPV), internal rate of return (IRR), and benefit and cost ratio $(\mathrm{B} / \mathrm{C})$, using a $7.5 \%$ discount rate. First, a negative value of $\mathrm{KRW} / 7.74$ million is obtained for the NPV. Since the discounted value of economic net benefits should be greater than zcro for a project to be economically viable, the conclusion is that the project is not coconomically viable.

Second, the internal rate of return (IRR) is also computed. The project's IRR is $1.77 \%$, and this value can be intcrpreted as an indication that society would obtain an average return of KRW'1.7? for cach KRW 100 invested in the project over a period of twenty years. Since the project's IRR is not cqual or greater than the chosen discounted rate of $7.5 \%$, the project is not conomically viable.

Last but not least, the benetic and cost ratio is not greater than 1.0 and the project is also not acceptable based on the benefit and cost ratio criterion. As a reference, international development finance organizations like the World Bank and the Asjan Development Bank use betwecn 10 and $12 \%$ as a discount rate. If one follows such a practice, the NPV and IRR of the BOI. project would be much lower, and the BOL project would be judged a poorer investment.

Table 5. Testing; the foonomic Vlability of the Samil.Ro ROl. Projecil

\begin{tabular}{|c|c|c|c|c|c|c|c|c|c|}
\hline & \multicolumn{3}{|c|}{ Cost (KRW million) } & \multicolumn{3}{|c|}{ Bencfit (KlRW million) } & \multicolumn{3}{|c|}{ Valuation } \\
\hline & $\begin{array}{c}\text { Capital } \\
\text { Costs }\end{array}$ & $\begin{array}{c}\text { Operating } \\
\text { Cost }\end{array}$ & Total & VOT & vol: & Total & $\begin{array}{c}\text { NPV } \\
\text { (a)illion) }\end{array}$ & IRR & $\mathrm{B} / \mathrm{C}$ \\
\hline $\begin{array}{c}\text { Before } \\
\text { Discountec: }\end{array}$ & 12,970 & 2,622 & $15,59]$ & $.7,820$ & 240 & 18,060 & & & \\
\hline $\begin{array}{c}\text { After } \\
\text { Discounted }\end{array}$ & $12,3 / 6$ & 942 & 13,318 & 8,450 & 114 & 8,563 & & $1 .: \%$ & $0.0 \%$ \\
\hline
\end{tabular}




\section{UNCERTAINTY AND SUSTAINABILITY OF THE PROJECT}

\section{Sensitivity and Risk Analysis}

The results obtained from a valuation of costs and benefits can be very sensitive to some of the assumptions employed in the monetary quantification of the benefits derived from the project. Because of this, a discussion of the changes that would take place if some assumptions are modified should compliment the results of the analysis. More precisely, we evaluate the impact of the changes in the value of time savings. Table 6 summarizes the results of scnsitivity and risk analysis when the value of time savings decreases by $5 \%$ percent. It shows the estimated value of a sensitivicy indicator (SI) and a swirching value (SV). A sensitivity indicator (SI) compares the percentage change in a variable and the percentage change in measure of project worth, while a switching value (SV) identifies the percentage change in a variable needed for the NPV ro become zero, the IRR to fall to the cut-off rate, and the project decision to change (ADB 1997). The scnsitivity indicator is 2.33 , and the value of time savings would need to be $42.92 \%$ lower for the NPV to fall to zero. Thus, the project is relatively sensitive to changes in the value of time savings and has a relatively small margir for a negative decision on the investment. In other words, if the value of the time savings due to the BOL project declines by 5\%, the IRR declines by $35 \%$, and the NPV declines by $12 \%$. Even if the NPV is positive, if the valuc of time savings declined by about $43 \%$, the BOI. project should have been rejected as it is an unviable project.

Table 6. Sexsitivity AND Risk AValysis Restlts

(Lnit: KRW million)

\begin{tabular}{l|c}
\hline & If the Value of Time Saving changes by $-5 \%$ \\
\hline VOT in the base case & 8,449 \\
NPV in the base case & $-4,754$ \\
IRR in the bast case & $1.77 \%$ \\
\hline VOT in the sensitivity sest & 8,027 \\
NPV in the sensitivity test & 5,308 \\
IRR in the Sensitivity test & $1.15 \%$ \\
\hline Sensitivity Indicator (SI) & 2.33 \\
Switching Value (SV) & $42.92 \%$ \\
\hline
\end{tabular}

\section{Environmental Sustainability Test}

The value of environmental effects can be included in economic analyses of projects, 
but is is often very difficult to place monetary value on all types of environmental effects (AI)B 1997 ). In this section, we will check the environmental sustainability of this projer by estimating the tegeree of covironmestat degradation resulting from the project and translating, it into monctary value.

Hete, we also use the basic data estimated in the KDJ report regarding the emission rate of $\mathrm{CO}, \mathrm{HC}, \mathrm{NOx}$, and $\mathrm{PM}$ when a private vehicle and bus travel one kilometer. The report also estimates the monctary value of air pollurion for each pollutant emission (Tables 7 and 8 ).

IAISLE 7. POLLITANT FMISSION RATHS

\begin{tabular}{|c|c|c|c|c|}
\hline & $\mathrm{CO}$ & 1.16 & Nox & $P_{M}$ \\
\hline Prisute vache & 1.37 & (1).3i) & $0.3 \div$ & i: $(m)$ \\
\hline Bus & $\therefore 41$ & 0.19 & 0.1 & 1. If \\
\hline
\end{tabular}

SOLRCE: Karea Developmen: Irjaticite 200]

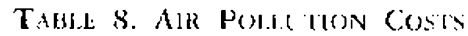

\begin{tabular}{|c|c|c|c|c|}
\hline & (c) & $\mathrm{HC}$ & $\mathrm{VO} \mathrm{O}_{\mathrm{x}}$ & $\mathrm{PM}$ \\
\hline ['rivale Volicks: & 0.43 & $2.6: 1$ & ? 们 & 0.019 \\
\hline Bus & 8.14 & 22.24 & 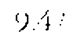 & 22.60 \\
\hline
\end{tabular}

SOCRCY: Kurea Derelopme:t Instutute 201

As seen in the previous section, the project itself triggered more buses to travel on Samil-Ro, but failed to shift private vehicle drivers inco public bus riders. Consequenty, numbers of both private vehick and bus are projected to increases, especially in the morning. When the number of buses obscrved increases, it may be due to the increase in speed as well as to the additional number of buses that may have been plit inco operation as part of the project. However, Seoul City confirmed that no additional number of buses was put into operation on the Samil. Ro as part of the project. Iherefore, we call infer that the increase in the number of buscs observed at the observation stations may be due entirely to the increased hus speced resuling from the project. From an cnvironmental impact point of view, it does not matter whether the increases it the mumber of buses observed are due to the net addition of buses put into operation or due to the faster bus mornaround operating on Samil-Ro. They would both create the same amount of air pollution. Thus, for practical reasons, we assums that the increased number of huses operating on Samil-Ro with the project is due to additional buses put into operation.

Basced on the information in Tables 7 anc: 8 , we estimated the value of annual emviromental degradation in Iable 9. 


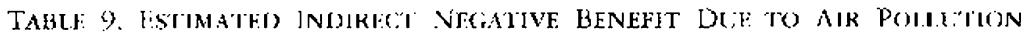

\begin{tabular}{|c|c|c|c|c|c|c|}
\hline & \multicolumn{2}{|c|}{$(0)$} & \multirow{2}{*}{$\begin{array}{c}\mathscr{\%} \\
\text { increase }\end{array}$} & \multicolumn{2}{|c|}{$\mathrm{HC}$} & \multirow{2}{*}{$\begin{array}{c}\mathscr{F} \\
\text { increase }\end{array}$} \\
\hline & Without & With & & W'ithout & With & \\
\hline Privite Veluicle & 0. & 10.2 & $0.98 \%$ & $: 7.9$ & $18:$ & $0.98 \%$ \\
\hline \multirow[t]{3}{*}{ Bus } & 17.6 & 18.9 & $780 \%$ & 6.2 & $6 . ?$ & $7.80 \%$ \\
\hline & \multicolumn{2}{|c|}{$\mathrm{Nox}$} & $\%$ & \multicolumn{2}{|c|}{ PM } & $\not z$ \\
\hline & Without & With & increase & Without & With & increase \\
\hline Private Velucie & \イ̂.। & $4 \ldots$ & $0.98 \%$ & 0 & 9 & $0.6(3) \%$ \\
\hline Bus & 10.1 & 0.8 & $7.80 \%$ & 16.1 & $1 / .3$ & $1.80 \%$ \\
\hline
\end{tabular}

Morcover, when we convert the future value of environmental degradation over next twenty years inro present value at a discoust rate of $7.5 \%$, we get a ncegative bencfit value of KRW45 million, which will further aggravate the NPV from KRW 4,754 million to KRW 4,799 million. If we take into account this negative bencfit derived frum the environmental degradation effect of the BOL system, the IRR and $\mathrm{B} / \mathrm{C}$ will also become smaller than the values estimated without considering environmental effects, i.e., 1.77 and 0.63 , respectively, forcing us to make a more negative jutgment on the economic viability of the $\mathrm{BOL}$ project.

\section{CONCLISSIONS AND LESSONS LEARNED}

In response to increased demand for better quality of public transportation as well as varous problems that arose from a sharp increase in private car ownership, many major cities around the world began studying and implementing bus-only-lane systems. We examined several international cascs in the beginning of this paper and focused on Sanzil-Ro Bus-Only-Lanc, one of the representative BOLs in Scoul, to evaluate the project's economic viability.

Hirst, we estimated travel demand on Samil-Ro was both without and with the project, and examined whether the project's goal of decreasing the number of provate vehicles was achieved. The ohserved results are negarive. It rurno out that regular conmuters who travel by private vehicles find the bus system less convenient and more rime-consuming than before, while only bus travelers found the new system relatively fasrer and more convenient. The bus operates through an exclusive lane with no jams or bottlenecks. In ocher words, the project enabled the Project Entify (Seoul City) to lise road surface more efficiently. However, it did not encourage private vehicle cravelers to become the bus users.

Second. the cost-benefit analysis condusted showed that the project is not economically viable. The discounted net present value (NPV) is less than zero, and the 
internal rate of return (IRR) is not equal to or greater than the chosen discounted rate, $7.5 \%$. Morcover, the benefit and cost ratio $(\mathrm{B} / \mathrm{C})$ is not greater than 1.0 , which means that this project is not economically acceptable. Lastly, the project also shuws low performance in uncertainty and sustainability tests. The project is rather sensitive to the value of time savings and has a small margin for crror or change in the esrimared value of travel time savings. Moreover, the project's economic viability is expected to be aggravated when considering the future value of environmental degradation.

In short, of its two main objectives, the Samil-Ro Bus-Only Lane project seems to have achieved only one goal: enhancing the speed of the bus system. The other goal of mitigating traffic jarns by decreasing the number of private vehicle commuters and increasing that of bus riders has not been realized; instcad, private vehicle traffic jams have worsencd.

To enhance the project's effects and achieve its arriculated goals, the Scoul Metropolitan Government may want to make similar studies for BOLs in Seoul as well as in other citics of the world. It should make an in-depth study of the reasons for failed objectives and carefully compare them with experiences of orher cities.

In the meantime, it would be worthwhile to improve the level of service on the bus system. Herer since the new bus system went into effect, there have becn numerous accidents and technical errors that increase waiting time for buses and traffic jams, even in bus-only lanes. Before launching significant investment projects in the future, public authorities should conduct rigorous economic analyses of the project and test it on a pilot hasis, comparing its viability with those of alternative investment opportunities. In turn, this will cnsure the best use of public funds.

\section{REFERENCES}

Asian Development Bank. 1997. Guidelines for the Economic Analy is of Projects. Manila. Belli, Pedro, Jock R Andcrson, Howard N. Barnum, John Dixon, and Jee-Peng Tan. 2001. Economic Asalysis of Investment Operations.' Analytical Tools and Pratical Applications. Washington, D.C.: the World Bank.

Chon, Kyung Soo. 2004. Toward a Sustainable Transportation System: New Transportation Policies in Seoul. Presented at the International Workshop on the Asian Approach toward Sustainable Urban Regeneration, September 4-7. Tokyo, Japan: Center for Sustainable Urban Regeneration, University of Tokyo.

Lee, Hoon-Ki and Jong-Hak Kim. 2004. Heffects of Thansport Environmental Improvement by Integrating $B K I$ and Road Pricing Measurer (March). Seoul: Korea Research Institute for Human Settlements, Kuk-Tu-Yun (In Korcan).

Korea Development Institute (KDI). 2001. Guidelines for Evaluating the Plausibility of large-scale Construttion Btusiness. Scoul: Regionial Ecurnornic Development (In Korean). 
Seoul City Office of Infrastructure Managenent, 2004. Final Auditing Reports on the Samil-Ro Remodeling Construction. Secoul (In Korean). 2004. Manitoring Traffic Flows on Sumil-Ro: Results of the Bus-Only lane Construction. Seoul (In Korean).

Seoul Metropolitan Government Transport Statistic. Available: http//www.seoul.go.kr/ seoul/summary/statistics/satistics seoul/today/1214656_10585.html

Seoul Merropolitan Government. 2004. Understanding the Bus System Reform in Seoul. Seoul: Transportation Bureau (In Korean).

UNESCAP. 2003. Review of Developments in Transport in the ESCAP Region No. Si/kXCAP/2307. Bangkok.

\section{ENDNOTES}

'UNESCAP (2003) argues that bus transport wiil continue to provide the most flexible and widely: used means of public transport for the forcsecable furuse despite the development of other public transporrations.

: The average annual rate of increase is culculated with data trom between 1995 and 2003 .

${ }^{3}$ The rate of delay represents a waiting time of vehicles (both private vehicles anci buses) at the red lights betore passing the intersector. The truffic signal system has not been changed with or without the projict

"This practice is callec "Standard Measures for Maintenance Costs." According to these measures, an average maintenatke cost for a standard f-lanes road during next twenty ycars after construction is estimatec at KRW4.3 billion.

'The number of privare vehicles is projected os increase from 42,942 to 43,362 in one year while that of bises is projecteat to increase from 3,690 (1) 3,978 in the saene period. 